\title{
APPROACHES TO DETERMINATION OF THE PROFESSION AND APPLICATION OF A SOCIAL PEDAGOGUE SEEN FROM THE PERSPECTIVE OF PEDAGOGICAL, PSYCHOLOGICAL AND MANAGERIAL THEORIES OF COMPETENCES ${ }^{1}$
}

\author{
Štefan Chudý, Svatava Kašpárková, Helena Řeháčková
}

\begin{abstract}
Before we start dealing with the theme of approaches to competences, it is necessary to define the concept of competence itself. In spite of the fact that this concept is no novelty in our dictionaries, there is a range of its possible explanations. For example, Otto's Encyclopaedia explains this concept as follows: "Competence is the entitlement and obligation of the authorities to handle issues which they are obliged to deal with in accordance with the law..." (1903, p. 710). The same explanation appears in the Czech language as well. Competence is therefore a total of entitlements and obligations, determines powers and provinces, but the difference is that today competence is also transferred on individuals and it therefore is not connected merely with organisations. Mainly encyclopaedic dictionaries interpret this expression as a "capability", they further state such synonyms as ability, qualification, experience, skill, etc. The differences in the interpretation of the concept of competence arise primarily from the understanding of the source of competence (competences) (see Mlčák, 2005, p. 29, Furnham, 1992, p. 54). In the first place, it is an attribute which is given from the outside, i.e. by an authority, and it is arranged by the society (Murény, 1993, p. 54, Mansfield, 1990, p. 25). Whereas the second interpretation explains it as a capability, where the inner attribute is emphasised, i.e. the quality of the capability is not determined by external environment, but depends on the individuality of the subject. Naturally, this meaning is used in scholarly literature in the field of personnel management, social pedagogy, and human resources, and in our paper, we are going to build on it as well. Pedagogical literature draws on a similar definition. The Research Institute of Education in Prague (RVP, 2005, p. 4) describes the term of competence as "a total of knowledge, skills,
\end{abstract}

1 This paper has been written within the work on the framework research grant "Determinants and development competences of social pedagogue in professional preparation", GACR 406/09/1220. 
capabilities, attitudes and value, which are important for personal development and utilisation of every member of the society".

\section{Key words}

Social pedagogy, competencies, theories of competencies, professional preparation of social pedagogue.

\section{Definition of the concept of competence from the perspective of managerial and psychological theories and taxonomies}

"Management by competencies $(\mathrm{MbC})$ is an approach taken to company management, which is based on a harmonious development of both 'hard' and 'soft' aspects of enterprise. Two worlds - i.e. the world of goals and requirements connected with performance, and the world of human resources and other assumptions of performance giving - meet here in a synergistic relation." (Plamínek, 2002, p. 16)

The essence of $\mathrm{MbC}$ lies in the fact that, in companies, requirements and limits represent, often to a large extent, separated worlds. As a result, problems frequently arise from the fact that the requirements made on performance do not correspond with current abilities of the company.

"MbC interconnects these two worlds and develops both components of this duality. It demands that they should develop in mutual harmony and thus support one another synergistically. It was not by accident that competences got into the name of methodology. As a matter of fact, prosperity of a company is immediately measured by achieved results. Nevertheless, foundation of this prosperity is actually seen in the competences of people who work for the company. Competences of people are perceived as a total of given performance (i.e. human labour) and provided potential (i.e. human resources). Provided that one of these is missing, competence as a whole is missing as well." (Plamínek, 2005, p. 24) The concept of competence is, without exception, related merely to specific assignments people are obliged to accomplish. From scholarly management-oriented literature (see Coomb, 1996, p. 54, Mansfield, 1996, p. 87, Winterton, 1999, p. 87 , Armstrong, 1999 , p. 85) emerges the fact that competences are most frequently divided into two groups, namely:

- threshold competences,

- differentiating competences. 
Threshold competences, which are defined as basic characteristics (knowledge, basic skills) and which are essential for performing assigned tasks, have no connection with excellent or above-average performance. Whereas differentiating competences are those that distinguish above-average performances from the average ones. By above-standard performance is usually understood each behaviour which exceeds average performance of the whole group at least by the value of one decisive variation. In this way, it is possible to differentiate between a competent and an incompetent individual.

In managerial literature (Kubeš et al., 2004, p. 28), there appears the well-known model of the so-called iceberg, which works with five basic components. These are:

- skills, which are acts that an individual is capable of and that help him or her to perform labour activities,

- knowledge, which represents what an individual knows about the subject in connection with the performed work,

- social role, by which an individual represents himself or herself towards the environment,

- self-image as a perspective from which an individual looks at himself or herself,

- traits are innate and permanent characteristics of an individual's personality,

- motives, i.e. incentives, which control an individual's behaviour.

When working with human resources, these components need to be differentiated. It seems to be appropriate to aim the attention not only to these competence determinants, but also to components which remain hidden (tacit, implicit knowledge, see Stuchlíková, 2005, p. 11). These components are very difficult to influence in a short period of time. However, they have to be taken into account because, on condition that the work lasts a long term, their development is possible. In his paper, Schröder (1989, p. 78) already specifically deals with competences which relate to the performance of a managerial office. The basic competences are then defined "as the knowledge and skills needed for a manager's work performance itself". They relate to specific assignments and ensure personal efficiency of the given individual. Competences of high performance are characterised by Schröder as rela- 
tively stable demonstrations of behaviour, owing to which whole teams led by a manager reach highly above-average results. Schröder actually defined the following eleven competences of high performance:

\begin{tabular}{|l|l|l|l|}
\hline $\begin{array}{l}\text { Cognitive } \\
\text { competences }\end{array}$ & $\begin{array}{l}\text { Motivational } \\
\text { competences }\end{array}$ & $\begin{array}{l}\text { Directional } \\
\text { competences }\end{array}$ & $\begin{array}{l}\text { Performance } \\
\text { competences }\end{array}$ \\
\hline $\begin{array}{l}\text { Obtaining } \\
\text { of information }\end{array}$ & $\begin{array}{l}\text { Interaction } \\
\text { management }\end{array}$ & Influence & $\begin{array}{l}\text { Orientation } \\
\text { to performance }\end{array}$ \\
\hline $\begin{array}{l}\text { Creation } \\
\text { of concepts }\end{array}$ & $\begin{array}{l}\text { Understanding } \\
\text { of other people }\end{array}$ & Self-confidence & $\begin{array}{l}\text { Orientation } \\
\text { to the target }\end{array}$ \\
\hline $\begin{array}{l}\text { Conceptional } \\
\text { flexibility }\end{array}$ & $\begin{array}{l}\text { Orientation } \\
\text { to development }\end{array}$ & $\begin{array}{l}\text { Presentation } \\
\text { of thoughts }\end{array}$ & \\
\hline
\end{tabular}

When dealing with classification of competences, it is imperative that we focus on another concept as well, namely emotional intelligence. By this concept, Goleman (1997) understands, apart from other things, the knowledge of emotions of one's self, the ability to control these emotions and motivate oneself. "Competences of emotional intelligence work synergistically with cognitive competences; first-rate workers possess both of them. The more complex the character of the particular work is, the more important role emotional intelligence skills play." (Goleman, 1997, p. 32) As a matter of fact, emotions have the power to intensify the effects of rational thought, or, on the contrary, to reduce them. By an analysis of more than 500 competence models, the author discovered that 80 to $90 \%$ of competences which distinguish above-average workers from the average ones belong to the sphere of emotional intelligence.

\section{The competence approach in auxiliary professions}

In the previous part of the paper, we were dealing with the definition and description of competences in the way they are perceived by current practice. This part of the text, however, discusses approaches to human resource management which build on limits and particularities of competences. Such an approach will help us to understand the essence of determination and training of competences.

The competence approach (or selection of the best candidate, proper management of his or her work performance, remuneration and career progress of the worker on the basis of his or her competences, which serve for 
reaching strategic objectives of the organisation) may be, in a modified form, applied also in the social sphere, which is not primarily focused on profit.

In the social sphere, it is very problematic to assess work performance (and thus also the competences of a social pedagogue). There are no uniform procedures and methods. This is caused partly by the fact that activities of a pedagogue are, for their complexity and creative character, in essence difficult to measure, partly by the fact that many meaningful and vocational work performances of a social pedagogue may lead to inefficient and unsuccessful performance.

In the Czech Republic, there are currently being applied two systems, which evaluate vocational competences of social workers. The first system was created on the basis of a recommendation made by the British National Council for Vocational Qualifications and compiled into the System of Practical Competences, which are determined as ... "functional demonstration of a well-managed and respected vocational role of a social worker, which includes professional knowledge, the ability to adequately reflect the context and sensitively apply the values of the profession" (Havrdová, 1999).

The second system was created by the Ministry of Labour and Social Affairs (MoLSA) as an Internet professiographic database under the name of Integrated System of Type Positions (ISTP, KTP, etc.), where two possible work positions are distinguished:

1. a social worker in social services - a specialist,

2. a professional social worker in social services.

Nevertheless, let us go back to the competence approach. Its application in a company results in a more efficient division of work among employees of the organisation. This consequently results in savings of the company's financial resources. As a result, productivity of labour increases, and financial investments in education and development are targeted. Transparent terms for individuals' career management are formed and competences of outstanding workers are clearly defined. These workers then serve as a model for many processes in human resource management.

However, in spite of great advantages, most companies have not adopted this approach, which is, in our opinion, caused by the fact that it is demanding to implement the competence approach into the work with human resources. 


\section{Application of competences}

To ensure a well application of the competence approach, it is necessary to satisfy several conditions:

- identification of competences which are essential for the particular position,

- compilation of a competence model,

- verification of the level of individuals' competences on work positions and ensurance of development in the required manner.

\section{Identification of competences}

Identification of competences is the most important measure in the competence approach. This should result in recognition of competences and behaviour which increases an individual's successfulness at the position he or she holds. These findings help us to compile an appropriate programme of development, to improve the successfulness of the choice, and set norms for performance. Naturally, it is important for us to be informed about plans and strategic objectives of the company and be able, by way of competences, to monitor the assigned target.

Competences may be identified by way of techniques of an analysis of work and the work position. Below in the text are described techniques and parameters of data, which are mutually complemented and combined (Spencer in Kubeš et al., 2004, pp. 48-55):

- A panel discussion of experts who work with success in leading positions - which results in quickly generated data and demonstrations of behaviour essential for the desired work performance. However, such characteristics do not always necessarily correspond with reality. Participants in the panel discussion may, for example, fall into thought stereotype in dealing with particular situations.

- Observation - serves to establish a broader context and detects also manners that a worker is not aware of. On the other hand, however, it is necessary to take into account distortion on the side of the observer.

- Interview - is focused on behaviour in crucial situations, in dealing with difficult moments.

- Research - results in quick obtaining of data from a wide circle of respondents. The limit may be directly asked questions, their potential misunderstanding, and not reflecting hidden behaviour and behaviour which is specific to, for example, the particular organisation. 
- Analysis of a work position - a description and an analysis of a work position enables specification of the position and thus clarification of its duties and functions.

- Database of competence models - represents a quick and inexpensive solution. Many consulting agencies create their own databases. However, the disadvantage of this technique appears to be the fact that thus created database cannot reflect specific conditions in the organisation, which has to be taken into consideration when choosing it, i.e. it is imperative to search for as many similar parameters as possible.

\section{Compilation of competence models}

"Competence models describe an enumeration of personality characteristics that are necessary for the accomplishment of assignments which are arranged into particular competences. In principle, the type of the model corresponds to the type of included competences. The model may be either specific or generic, furthermore a model of key competences of the organisation, or it is possible to build on competences which are essential for a successful worker in the given position. The selection of a particular model type is determined by the aim of its application." (Kubeš et al., 2004, p. 59) When creating a model, it is naturally possible to apply more approaches. A range of factors depend on their selection. Among the most important factors belong time and financial resources.

Rothwell and Lindholm (in Kubeš et al., 2004, p. 63) state three basic approaches: "Provided that a company does not create its own innovative model but makes use of a model which is already available on the market, we talk about a perspective (borrowed) approach. The advantage of promptness and relatively low expenses is counterbalanced by the fact that the model does not make an exact copy of the organisation's environment. Another possibility is the creation of a model which will adapt to the organisation's particularities. This model is called a combined model. The last alternative is to tailor the model to the needs of the organisation. It is necessary to re-identify and re-define the competences. This is clearly the most challenging approach, which, nevertheless, gives the most reliable foundations for personnel decisions."

\section{Verification of the level of competences}

To be able to effectively take advantage of the competence approach, it is important that we manage to determine the level of competences of particular workers. This means that the competence model describes the desired state 
of competences and the measurement itself then examines to what extent are certain competences of particular workers developed. The collected information will consequently help us to eliminate or reduce detected differences and it has a supportive impact on an individual's development. The measurement itself is very complicated, which is caused by the fact that interpretation of the competences themselves is not uniform.

The level of competences may be evaluated by data acquired mainly from three sources, i.e. on the basis of:

- self-evaluation,

- evaluation of subordinates,

- evaluation of superiors.

There is a wide range of methods that may be used for measurement. These methods differ in accuracy, in the time they consume and in appropriateness of their application. The decisive criterion for their selection should be, of course, reliability.

The above-mentioned methods may be primarily divided into those which originate in direct observation and the rest of them, such as analogue methods, various group exercises, playing roles, and case studies, on condition that the displayed behaviour is assessed directly, in the way it was provoked by the stimulus.

Among analytical methods are ranged tests of mental abilities and questionnaires, which examine temperament and motivation. These are largely psychometric means.

The most frequently used method, which applies direct observation, is an interview. "For the purpose of appraisal of the level of competences, an interview is used under the name of Competency Based Interview (CBI). CBI aims to direct the person who is being assessed at identification and analysis of preceding events and assignments, in which he or she played an important part. The person gives an account of how he or she behaved, what induced this behaviour, and what was the result. The evaluator subsequently examines the answers, searches for the occurrence of competences, and evaluates their levels. Selection of the task which is the object of the interview is crucial. The substance of the task has to be such a behaviour which gives evidence of the studied competences." (Kubeš et al., 2004, p. 80) 
Another alternative designated for obtaining of data is investigation via a questionnaire, which is not without imperfection because we obtain only the data we ask for in the questionnaire. The questions already cannot be either specified or clarified any further. Moreover, as far as closed questions are concerned, we have to take into account the fact that the answers will be limited by the selected option. Another drawback is seen in a low rate of return. On the other hand, the advantage of this method seems to be quick obtaining of data and the opportunity to address a large circle of people. The result may have either a qualitative or a quantitative form.

\section{The sphere of application}

The competence approach may be applied in the whole field of human resource management. Competences unite for us the perspective on future needs and manners of behaviour, which we support and reward.

The picture below shows us the possibilities of application of competences in the processes of an organisation (see picture No. 1).

Picture No. 1: Application of competences in the processes of human resource management (Kubeš et al., 2004, p. 149)

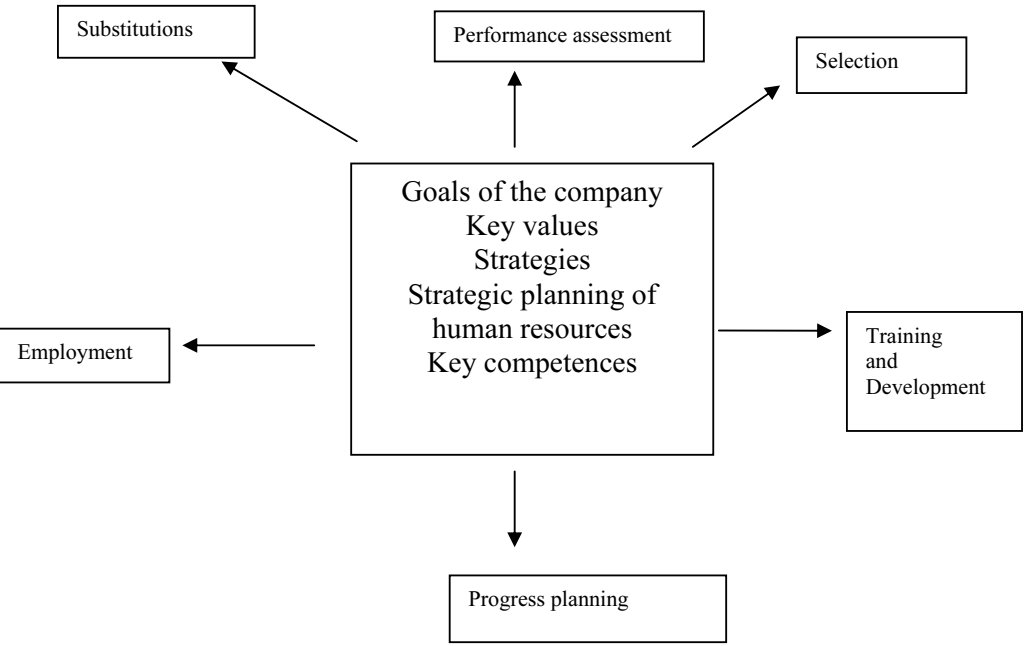


It is suitable to describe the interconnection of the processes and competences in detail. Provided that we select workers with the help of the competence model, we work with both the current and future requirements for the work position. As an appropriate situation for the application of competences in selection is stated, for example, a position with high turnover. If we specify the selection, the turnover will decrease. Such an approach is also favourable on condition that we search for workers from currently available human resources. In this way, we may better identify an individual's potential for the particular position and his or her further development.

Provided that we clearly define the competences, our work with the system of assessment and reward is thus facilitated. This is also favourable for the worker as he or she knows exactly what are the requirements he or she should meet. Assessment, which is found upon competences, helps to build the company's culture and refines relations within the organisation. What is of importance is continuous training of reserve forces in human resources of the organisation. Regular evaluation of the level of competences is compared with the requirements that current or future positions are expected to satisfy.

Career management is closely connected with workers' development. Provided that the development is based on competences, it is possible to approach it more compactly and, at the same time, this allows us to continuously develop the worker's readiness in connection with his or her current or future performance. A clear definition of competences ensures that the worker is conscious of the behaviour he or she should achieve, and thus also of the target of his or her development. Development of workers and competences is dealt with in next chapters.

\section{Definition of the concept of competence from the perspective of the social- -pedagogical theory}

Competences as a key concept are characterised by representatives of Czech and Slovak pedagogy as a collection of vocational skills (Průcha, 2001), the readiness to perform the demands of one's profession (Slavík, 1993), vocational qualities of a teacher (Vašutová, 2001), a complex ability or capability for successful performance of the profession (Spilková, 2004), and a total of capabilities for effective teaching and education and for the refinement of the pedagogical occupation (Švec, 1999). Content over-abundance and unclearness of the concept of competence is referred to by Janík (2005, 
p. 14): "While competences of a teacher are clearly defined, competences of a social pedagogue are difficult to determine accurately, to put into specific normative categories." For comparison, we present two characterisations of a teacher's competences as stated by V. Švec and Walterová. The model of abilities was elaborated by V. Svec (2000), who described the teacher's profession in the following three competence circles:

- competences designated for teaching and education,

- personal competences,

- developing competences.

These competences are further internally structured by abilities and skills. Follows the model of key competences as stated by Walterová (2001, p. 31):

- subject-area competences,

- didactic and psycho-didactic competences,

- general pedagogical competences,

- diagnostic and intervention competences,

- social, psycho-social and communication competences,

- managerial and normative competences,

- vocational and personality-cultivating competences.

The basic and, with regard to content, the most apt definition of key competences in social pedagogy is considered to be the interpretation by Bakošová (2005, p. 15), who perceives them in connection with activities, abilities, knowledge and specific skills of a social pedagogue. Bakošová interprets competences in a broader conception which includes also legal terminology (authority), which has hitherto implied professional authority in accordance with the level of education. She divides competences in the following way:

- educational competences,

- re-educational competences,

- consulting competences,

- prevention competences,

- managerial competences.

When defining competences, similar procedure was also used by Chudý (2006, p. 39), who, nevertheless, builds rather on the role and applicability 
of a social pedagogue in practice and on functions that the social pedagogue holds while practising his or her profession:

- a labour manager in social and educational institutions,

- a recogniser of educational and social problems,

- an adviser on issues of the application of social policy,

- a consultant on learning difficulties,

- an educator,

- an animator of children and young people's free time,

- an innovator of pedagogical-educational methods,

- a creative type in various social-educational institutions,

- a reflective professional (Chudý, 2005, p. 40, Kraus, 2001, p. 33).

In this conception of professional authority, the level of education and applicability in practice, general competences of a social pedagogue are specified as an intersection of competences:

- Educational competences

The social pedagogue as a co-author of the theory and practice of social pedagogy is, in the broadest sense of the word, an educator. He or she creates his or her own basis of educational strategies and subject matters, he or she makes use of the theoretical knowledge and reflects the practical knowledge. $\mathrm{He}$ or she is a solver of "educational reality" and works on the development of human personality. He or she makes plans, organises and assesses his or her educational activities on the basis of subjective criteria and criteria of state policy in the province in which his or her profession is practised.

\section{- Social-educational competences}

These competences include the knowledge and qualification to prepare, manage and evaluate programmes of pedagogical and social sort, and to strengthen the social basis of personality. This is grounded in the preparation of environment and implementation of given programmes for the purpose of building of human personality, capable of being an experienced member of the society, as well as of communicating. An important part of these competences is also the knowledge of personality, educational strategies and the influence of processes of pedagogical and educational transformation on human personality (self-education and self-instruction - compare e.g. Selická, 2010, p. 2). 


\section{- Prevention competences}

These competences embrace the skill of the social pedagogue to recognise deviations from the norms and to apply strategies to at-risk individuals and groups. The prevention may be divided as follows: primary (universal), secondary (selective), and tertiary (Matula in Bakošová, 2005, p. 18). Universal prevention focuses on organisation of activities which aim to create an atmosphere of reception of problems of various types. The competences include the knowledge of formation of instructional and educational programmes, as well as creation of short-term activities (workshops, etc.). Secondary prevention focuses on tracing people and directing them at rejection of undesirable elements in inappropriate environment. The knowledge basis is accomplished by activities connected with practising techniques and strategies, as well as building a web of relations.

\section{- Re-socialisational and re-educational competences}

Re-educational and re-socialisational competences enable the social pedagogue to respond to social and educational situation, which occurred and resulted in the emergence of social-pathological phenomena. Intervention (the concept is perceived as a collection of measures) is based on formation and evaluation of programmes aimed at an individual and groups.

\section{- Advisory competences}

Advisory work as a professional activity requires people to let themselves guide to better self-knowledge, to become aware of both weaknesses and strengths of personality, and to realise one's life goals. Not only resolution of problems, but also searching for causalities is of importance. Within miscellaneous psychological trends and movements may be encountered various advisory approaches (e.g. humanistic, psychoanalytic, cognitive-behavioural approach, etc.). For the purposes of the social-pedagogical practice, it is necessary to define basic assignments (e.g. Bakošová, 2005).

\section{- Diagnostic competences}

Diagnostic competences aid the social pedagogue in discovering the causes of states that emerged (social-pathological phenomena, etc.). This sort of competences necessitates not only terminological specification, but also a detailed description of the fields of focus. Our conception of fundamental 
fields of focus includes diagnostics of social aspects of education, diagnostics of the environment, diagnostics of particularities, and evaluation of employed diagnostic methods.

\section{- Methodological competences}

Methodological competences work on readiness and implementation of the social pedagogue's activities in the theoretical and practical sphere, and in the field of scientific research. The theoretical sphere embraces comprehension, description, reflection, interpretation, conception and orientation of the scientific discipline, and aims to adjust and elaborate the terminological definition of basic concepts and relations, as well as to specify internal scientific structures, which is based on theoretical research that is supported with practical reflection and interpretation of educational and social systems. The social pedagogue should be able to reflect reality and continuously put it to theoretical and empirical research.

\section{- Decision competences}

Decision competences are neither perceived from the technical and economic perspective, nor from the perspective of social policy, but from the perspective of key competence, which is the bearing competence and, at the same time, embraces dimensions of other competences and mingles particular competences in various extent and various content.

The specificity of these competences follows in particular from the impossibility of divorcing particular dimensions and targets of these competences from the other and describing them, and thus also particular activities of formation and development of decisive competences. The bearing activity is the arrangement of qualified orientation in the management of relations and activities of all the participants in the social-pedagogical process of education and instruction in particular environment. The social pedagogue is the coauthor of the environment in which children, young people and adults feel safe and welcome. He or she aims at a climate which necessitates involvement in further personal development, and employs methods of solidarity and co-operation. In family participation, he or she makes use of strategies of life organisation in a particular environment, which is interconnected with life of the village or the town. An important element is considered to be taking responsibility for the development of capabilities of clients (wards, 
inmates, etc.) within the particular institution. No less important sphere of the development of decisive competences is the artistry to pre-consider, allow play and evaluate upcoming situations with claimed responsibility for their creation and consequences for all the participants. A particular individual's gradual assumption of his or her own responsibility is part of the development of decisive competences not only over the whole period of his or her studies (preparation for professional practice), but frequently also over the period of whole life.

\section{Definition of the profession of a social pedagogue from the perspective of legis- lation in the Czech Republic}

The occupation, activities and work content of a social pedagogue are defined by the laws of the Czech Republic, in particular by Acts No. 108/2006, $563 / 2004$, and $257 / 2000$. Nevertheless, the content of his or her profession may be much more complex and demanding than it might seem. What we intend to touch here is precisely the interconnection between output competences and particular branches of professional practice, for which the social pedagogue should be prepared. Moreover, he or she often has to participate in complex running of the organisation in which he or she is employed. Most of the below-stated professions are mainly concerned with prevention in the social field. The summary stated below builds on scholarly publications of authors who specialise in particular spheres of activity of the social pedagogue.

\section{Social pedagogue as a social worker}

Application of the social pedagogue which focuses on social services is defined by the law as an occupation of a social worker $(\S 110$, Section 4, Act No. 108/2006 Coll., on Social Services, as amended). Further are defined principles of pedagogical support: dialogue (interaction), selforganisation (activity), sensomotorics (game), construction (creation), symbolism (illustration), balance (divergence). In institutions ensuring social services, the social pedagogue performs pedagogical activities in accord with Act No. 563/2004 Coll., on Pedagogical Workers, as amended. Within the field work in a family, the social pedagogue encourages, for example, a senior citizen to engage in a collective activity with a child, which enables them to enrich one another by, for example, a collective activity, reading a book aloud, or creating tiny articles, etc. 


\section{Social pedagogue as an educator}

The social pedagogue may implement educational activities as an educator in educational institutions ( $§ 16$, Section 1, Act No. 563/2004 Coll., on Pedagogical Workers, as amended). Particular educational institutions ensuring free-time activities with requisite professional qualification are specified by Hájek et al. (2008). These are namely educational institutions which specialise in institutional education (diagnostic institution, children's home, school and children's home, and educational institution), drop-in centres, non-governmental and non-profit organisations, including civic associations. The educator participates in organisation of free-time activities of the service users, he or she should be equipped with the knowledge from the field of developmental psychology because every age group of children placed in his or her charge may have different requirements and needs. What is considered to be crucial are his or her personal interest and individial approach, acquaintance with the technique of active listening, and familiarity with effects of the therapy. Children who, for social reasons, find themselves in children's homes and the above-mentioned institutions, experience a complicated and demanding period when, apart from pedagogical and direct educational influence of the educator, they first and foremost need an illustrative example of good and appropriate behaviour. When communicating with children, it is necessary to be prepared for their frequent inquiries. The educator therefore becomes their adult model, which they will not forget, they may follow his or her behaviour and perspectives on life. As a result, the qualities that the social pedagogue may apply include in particular positive encouraging and the knowledge of both the fields of psychology and family law. Children who live in children's homes create a very emotional bond with the educator, and he or she then has to consider what approaches or social relations he or she will choose to retain appropriate emotional relations and detached pedagogical perspective.

\section{Social pedagogue as a free-time pedagogue}

The profession of a free-time pedagogue is a very interesting and creative activity that works with children and young people (§ 17, Act No. 563/2004 Coll., on Pedagogical Workers, as amended). Social direction leading towards integration of children into collective activities of group spending of free time is organised by the social pedagogue in accordance with a pre-prepared conception, which embraces acquaintance with users of the activities, the knowledge 
of the given locality, and familiarity with individual desires and limits of the children. To strengthen the family relations, the social pedagogue should also involve the users' parents or even the whole broad family of the child into organisation of young people' free time. As Průcha (2006) puts it, free-time pedagogy functions as a preventive measure to minimise aggression, delinquency, and other unwelcome phenomena which occur in the behaviour of children and young people. He mentions the concept of animation, the method of non-directive encouragement of activities and self-realisation of young people. Furthermore, he states institutions in the Czech Republic which are part of the system of educational institutions concerning free-time education: elementary art schools, language schools, after-school care centres and schools clubs, centres, and children and youth centres. He speaks of insufficient research, which might produce much more information even on the effect of media on young people and relations within groups. An important factor of the social pedagogue's activities is communication with young people and children, where the essential consideration is detecting in what type of activities are they particularly interested. In our opinion, a child should choose his or her free-time activity especially from the sphere in which he or she is interested and which he or she enjoys and is thus able to develop his or her talent or endowment. As a matter of fact, it is infelicitous to urge the child to an activity which would annoy him or her, or which would be a burden for him or her. Free time of young people is especially about becoming less worried about school duties, and the social pedagogue's task is running of friendly relations within youth groups while spending their free time by joint activities.

The social pedagogue is therefore a methodist, and he or she checks retrospectively whether the selected activity fulfils the children's interest, and thus, at the same time, accomplishes a preventive function of the activity. Among his or her aptitudes hence belong a set of proposals of free-time interest activities, their elaboration, and diversity, but also pedagogical supervision, which, in most cases, lacks any marking of the results of the children's activities. Especially little children require much attention and creativity. On the market, there are nowadays many books which contain inspiration for hand-making of various tiny articles, also many children's games as well as drawing tools, or varied sporting activities. The social pedagogue guides and encourages children in selected activities, and, at the same time, he or she is able to provide them with psychological and positive support. $\mathrm{He}$ or she 
shows them how to solve and proceed with their problems. Pedagogical social management also includes the method of a dialogue, by which the pedagogue influences desirable proceeding in dealing with a problem or conflict the child meets with either in the family or at school. He or she must not belittle the significance of the child's account and has to consult the situation with other professional workers. The mass media interfere in the life of children and young people more and more intensively owing to the Internet, radio, television, and advertising propaganda. The social pedagogue makes a change in the child's daily routine and affects its arrangement, which enables him or her to prevent the child from being lonely and becoming integrated into groups which spend their free time by using addictive substances. Timetabling of the child's daily activities is important, and it strengthens family relations or relationships with one's peers.

\section{Social pedagogue in practice of a pedagogue's assistant}

A challenging role of the social pedagogue, particularly in the competence of special pedagogical occupation, is working in the office of a pedagogue's assistant ( $§ 20$, Act No. 563/2004 Coll., on Pedagogical Workers, as amended). According to Valenta et al. (2003), a pedagogue's assistant is at elementary schools largely perceived as the most important element of special pedagogical assistance, designated especially for children with physical or mental handicaps. The pedagogue's assistant provides the integrated pupil with support within the given individual scope.

Integration of a health disadvantaged pupil into the group of his or her classmates, dealing with communication problems within the class by the role a pedagogue's assistant, and allowance of a pupil's individual studying plan is within the education itself a great progress and success, both in practical schooling and in legal embedding in the legal code. Considering the abovedescribed work content, the role of a pedagogue's assistant is a very demanding function because it embraces aptitudes of special pedagogy competences, and the knowledge of medical problems and psychology.

Within the institutions providing pedagogical activities, the work content of pedagogues also includes administrative work containing management and filing of documents. The pedagogue's assistant participates in recording in accordance with relevant organisational procedures and rules of the given institution. 
As Hájek et al. (2008) argue, by documentation are meant statistical reports, attendance book, a survey of pedagogical-educational work, personal documents, daybooks of interest units, daily records, school register, and daybooks of educational groups according to the particular educational institution. Furthermore, this includes specific documents concerning children's register, school educational program, class register, injury register, minutes of inspections, and other required documents and archive materials.

\section{Social pedagogue as a clerk or an assistant Probation and mediation services}

An interesting sphere of the social pedagogue's activity may be working in criminal-law field of probation and mediation, including preventive measures of criminal activities ( $\$ 6$, Act No. 257/2000 Coll., on Probation and Mediation Service, as amended). As Fischer (2006) puts it, of crucial importance are activities of pedagogical workers in ensuring optimal regime of custody performance in accordance with the requirements of the European Prison Rules, which demand preservation of human health and his or her natural dignity. As far as underage persons are concerned, the rules ensure an offer of educational activities, appealing to spiritual needs, recommendation of literature, support of the principle of humanisation, and lowering the intensity of stressful situations of the prison environment. The social pedagogue may also provide, within the sphere of activity of a commissioned person, social-law child protection.

\section{Conclusion}

The development of social pedagogy as a modern pedagogical discipline may be nowadays considered one of the important factors of improvement of the quality of human life in the society. Much attention should be paid to the preparation for the profession of a social pedagogue, especially considering the wide scope of practical application of this profession.

In this particular text, we have tried to summarise the already discovered theoretical information on the competences, profession, and mostly used definition of the occupation of a social pedagogue. At the same time, we are aware of the fact that these definitions are not able to completely express the fundamental basis of the theory of social pedagogy and its professionalisation in the system of pedagogical sciences. 


\section{Literature}

ARMSTRONG, M. Managing People: A Practical Guide for Line Managers. London: Kogan Page Ltd., 1998. ISBN 0-7-494-2612-8.

BAKOŠOVÁ, Z. Sociálny pedagóg a jeho kompetencie. In Pedagogická revue, vol. 57, 2005, no. 1, pp. 12-21. ISSN 1335-1982.

BAKOŠOVÁ, Z. Sociálna pedagogika ako životná pomoc. Bratislava: STIMUL, 2005. ISBN 80-89236-00-6.

FISCHER S. Etopedie v penitenciární praxi. Ústí nad Labem: Univerzita J. E. Purkyně v Ústí nad Labem, 2006. ISBN 80-7044-772-9.

FURNHAM, A. Personality at Work: The Role of Individual Differences in the Workplace. London: Routledge, 1992. ISBN 0-415-03547-3.

GOLEMAN, D. Emoční inteligence. Praha: COLUMBUS, 1997. ISBN 80-85928-48-5.

HAVRDOVÁ, Z. Kompetence v praxi sociální práce. Praha: Osmium, 1999. ISBN 80-902081-8-5.

CHUDÝ, Š. Possibilities for Research into the Development of Pedagogical Skills in Resolving Educational Situations. In The Educational Review. Vol. 11, No. 1, 2007, pp. 21-37. ISSN 1732-6729.

CHUDÝ, Š. Kompetencie sociálneho pedagóga ako klúčová kategória sociálnopedagogickej pedeutológie. In Sociální pedagogika v teorii a praxi. Brno: IMS, 2006. ISBN 80-902936-7-0.

JANÍK, T. Znalost jako klíčová kategorie učitelského vzdělávání. Brno: Paido, 2005. ISBN 80-7315-080-8.

KUBEŠ, M a kol. Manažerské kompetence: způsobilosti výjimečných manažerů. Praha: GRADA, 2004. ISBN 80-247-0698-9.

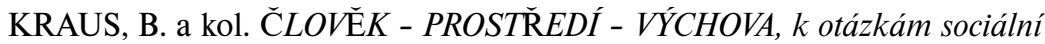
pedagogiky. Brno: Paido, 2001. ISBN 80-7315-004-2.

MANSFIELD, B., MITCHELL, L. Towards a Competent Workforce. London: Gower, 1996.

MLČÁK, Z. a kol. Profesní kompetence sociálních pracovníků a jejich hodnocení klienty. Ostrava: FF OU, 2005. ISBN 80-7368-129-3.

PLAMÍNEK, J., FIŠER, R. Řizení podle kompetencí. Praha: GRADA, 2005. ISBN 80-247-1074-9.

PLAMÍNEK, J. Vedení týmů a firem: praktický atlas managementu. Praha: GRADA, 2002. ISBN 80-247-0403-X. 
PRŮCHA, J.; WALTEROVÁ, E.; MAREŠ, J. Pedagogický slovník. Praha: Portál, 2001. ISBN 80-7178-029-4.

Rámcový vzdèlávací plán. Praha: Výzkumný ústav pedagogický, 2005. ISBN 80-87000-02-1.

SELICKÁ, D. Sociálny pedagog v školskom prostredí. Vychovávatel'. 2010, vol. LVIII, no. 7, pp. 2-3. ISSN 0139-6919.

SCHRÖDER, H. Managerial Competence: The Key to Excellence. Dubuque, IA: Kendall Hunt, 1989. ISBN 0840355408.

SLAVÍK, J., SIŇOR, S. Kompetence učitele v reflektování výuky. Pedagogika, 43, 1993, no. 2, pp. 155-164. ISSN 0031-3815.

SPILKOVÁ, V. et al. Současné proměny vzdělávání učitelů. Brno: Paido, 2004. ISBN 80-7315-081-6.

STUCHLÍKOVÁ, I. Implicitní znalosti a intuitivní pojetí v pedagogické praxi. In ŠVEC, V. (ed.) Od implicitních teorií výuky k implicitním pedagogickým znalostem. Brno: Paido, 2005. ISBN 80-7315-092-1.

ŠVEC, Š. Základné pojmy v pedagogike a andragogike. Bratislava: IRIS, 2002. ISBN 80-89018-31-9.

ŠVEC, V. (ed.) Monitorování a rozvoj pedagogických dovedností. Brno: Paido, 2000. ISBN 80-85931-87-7.

VAlentA, M., MÜller, O. Psychopedie. Praha: Parta, 2003. ISBN 80-7320-039-2.

VAŠUTOVÁ, J. Kvalifikační predpoklady pro nové role učitelu․ In: WALTEROVÁ, E. (ed.) Učitelé jako profesní skupina, jejich vzdělávání a podpůrný systém. Praha: Univerzita Karlova - Pedagogická fakulta, 2001. $1^{\text {st }}$ volume, pp. 19-46.

WALTEROVÁ, E. (ed.) Učitelé jako profesní skupina, jejich vzdělávání a podpưrný systém. Praha: Univerzita Karlova-Pedagogická fakulta, 2001. $1^{\text {st }}$ and $2^{\text {nd }}$ volumes.

WINTERTON, E. Developing Managerial Competence. Routledge and Falmer, 1999. ISBN 0-415-18345-6.

Act No. 108/2006 Sb., on Social Services.

Act No. 563/2004 Sb., on Pedagogical Workers.

Act No. 257/2000 Sb., on Probation and Mediation Service. 


\section{Contact}

Štefan Chudý

Univerzita Palackého v Olomouci

Pedagogická fakulta, ÚPSS

Žižkovo nám. 5

77140 Olomouc

Svatava Kašpárková, Helena Řeháčková

Univerzita Tomáše Bati ve Zlíně

Fakulta humanitních studií

Nám. TGM 5139

76001 Zlín 